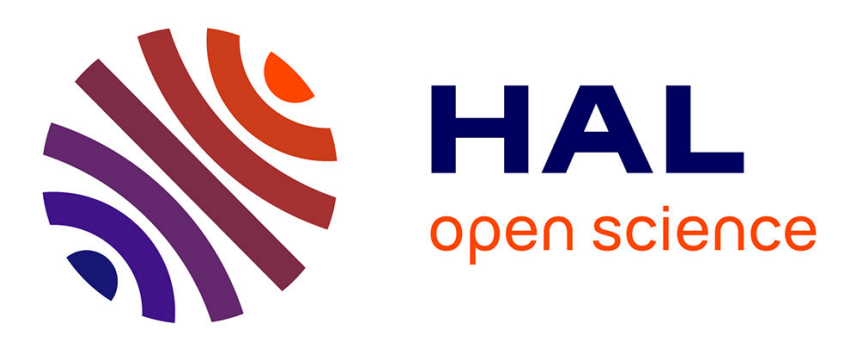

\title{
Synthesis and receptor binding affinity of carboxylate analogues of the mannose 6-phosphate recognition marker.
}

Audrey Jeanjean, Marcel Mg Garcia, Alain Leydet, Jean-Louis Montero, Alain Morère

\section{To cite this version:}

Audrey Jeanjean, Marcel Mg Garcia, Alain Leydet, Jean-Louis Montero, Alain Morère. Synthesis and receptor binding affinity of carboxylate analogues of the mannose 6-phosphate recognition marker.. Bioorganic and Medicinal Chemistry, 2006, 14 (10), pp.3575-82. 10.1016/j.bmc.2006.01.024 . inserm00144764

\section{HAL Id: inserm-00144764 https://www.hal.inserm.fr/inserm-00144764}

Submitted on 7 May 2007

HAL is a multi-disciplinary open access archive for the deposit and dissemination of scientific research documents, whether they are published or not. The documents may come from teaching and research institutions in France or abroad, or from public or private research centers.
L'archive ouverte pluridisciplinaire HAL, est destinée au dépôt et à la diffusion de documents scientifiques de niveau recherche, publiés ou non, émanant des établissements d'enseignement et de recherche français ou étrangers, des laboratoires publics ou privés. 
Synthesis and receptor binding affinity of carboxylate analogues of the Mannose 6-Phosphate recognition marker

Audrey Jeanjean, ${ }^{a}$ Marcel Garcia, ${ }^{b}$ Alain Leydet,${ }^{a}$ Jean-Louis Montero, ${ }^{a}$ and Alain Morère ${ }^{a, *}$

a Laboratoire de Chimie Biomoléculaire, Université Montpellier II

Ecole Nationale Supérieure de Chimie de Montpellier, 8 Rue de l'Ecole Normale

F-34296 Montpellier Cedex 05, France

E-mail : morere@univ-montp2.fr

Tel : Int +33467144345

Fax : Int +33467144344

b INSERM, Unité 540, EMCC, 60 Rue de Navacelles, F-34090 Montpellier, France

\begin{abstract}
:
The mannose 6-phosphate/ insulin-like growth factor II receptor (M6P/IGF2R) is involved in multiple physiological pathways including targeting of lysosomal enzymes, degradation of IGF2 and cicatrisation through TGF $\beta$ activation. To target potential therapeutics to this membrane receptor, four carboxylate analogues of mannose 6-phosphate (M6P) were synthesized. Three of them, two isosteric carboxylate analogues and a malonate derivative, showed a binding affinity for the M6P/IGF2R equivalent or higher than that of M6P. On the contrary to M6P, all these analogues were particularly stable in human serum. Moreover, these derivatives did not present any cytotoxic activity against two human cell lines. These analogues represent a new potential for the lysosomal targeting of enzyme replacement therapy in lysosomal diseases or to prevent the membrane-associated activities of the M6P/IGF2R.
\end{abstract}




\section{Introduction}

The mannose 6-phosphate (M6P) is a recognition marker involved in the selective targeting of newly synthesized lysosomal enzymes from the trans-Golgi network (TGN) to endosomes. Sorting and transport of lysosomal enzymes are ensured by two receptors, the $46 \mathrm{kDa}$ cation dependent-M6P receptor (CD-M6PR) and the $300 \mathrm{kDa}$ cation independent-M6P receptor (CIM6PR). After releasing of enzymes, the receptors are recycled back to the Golgi apparatus or move to the plasma membrane, where the CI-M6PR internalizes exogenous lysosomal enzymes while CD-M6PR is unable to endocyte hydrolases. ${ }^{1}$ In addition to its ability to recognize M6P-containing proteins, the CI-M6PR is implicated in many other physiological processes. CI-M6PR is known as M6P/IGF2R since it binds the non-glycosylated insulin-like growth factor II (IGF2) at the cell surface. Binding of this growth factor is followed by internalization and subsequent degradation in the lysosomes. ${ }^{2}$ The M6P/IGF2R also binds retinoic acid (RA) with high affinity at a binding site that is different from those for IGF2 and M6P on the receptor. ${ }^{3}$ In addition to lysosomal enzymes, the M6P/IGF2R binds other M6Pcontaining proteins, including for instance the Granzyme $\mathrm{B},{ }^{4}$ which is a protease involved in cytotoxic-T-cell-induced apoptosis, or the latent transforming growth factor- $\beta$ (LTGF- $\beta$ ) complex, which is activated at the surface of the receptor. ${ }^{5}$ Moreover, several clinical studies indicated that the M6P/IGF2R could act as a tumour suppressor. Indeed, overexpression of the receptor acts as a growth inhibitor ${ }^{6}$ while loss of receptor function is associated with progression of tumorigenesis. $^{7}$

In the laboratory we focused on the M6P/IGF2R ability to bind extracellular M6P-bearing ligands in the hypothesis to use this receptor as a therapeutic target. To better understand the molecular basis for the interaction of the M6P/IGF2R with M6P, we synthesized several carboxylate and malonate analogues of $\mathrm{M} 6 \mathrm{P}$ and we studied their binding affinities for the M6P/IGF2R. In an attempt to use these synthetic analogues in therapeutical approaches we also evaluate their stability in serum and their cytotoxicity in human cells.

\section{Results and discussion}

The M6P/IGF2R is a type I transmembrane glycoprotein which possesses four structural domains: an amino-terminal signal sequence, an extracytoplasmic region which contains the different binding sites, a transmembrane region and a carboxyl-terminal cytoplasmic domain. The large extracellular domain has a structure consisting of 15 contiguous repeating domains. The sequence homology between the 15 repeating segments suggests that the M6P/IGF2R 
could contain 15 M6P binding sites. In fact, experiments revealed that the M6P/IGF2R binds only 2 mol of M6P. ${ }^{8}$ The presence of two different carbohydrate recognition domains in the M6P/IGF2R provides this receptor with a functional advantage over the CD-M6PR, which contains only one. This difference certainly explains why the M6P/IGF2R recognizes a wider spectrum of lysosomal enzymes than does the CD-M6PR. ${ }^{9,10}$ For instance, the M6P/IGF2R, unlike the CD-M6PR, binds very efficiently Dictyostelium discoideum lysosomal enzymes, which contain in their structure the phosphodiester Man- $\mathrm{P}-\mathrm{OCH}_{3}{ }^{11}$ and the mannose 6-sulfate $(\mathrm{M} 6 \mathrm{~S})^{12}$. These findings are particularly interesting because they demonstrate that a single negative charge on the phosphate moiety, as well as on the sulfate group, is sufficient to preserve the recognition phenomenon by the M6P/IGF2R. Another structural factor, which contributes in the binding to the M6P/IGF2R, is the axial 2-hydroxyl group in the M6P. Indeed, glucose 6-phosphate, the 2-epimer of M6P, is a poor inhibitor for the M6P/IGF2R. ${ }^{13}$ On the other hand, the hydroxyl group at the anomeric position of M6P appears to be unimportant in the binding to the receptor. ${ }^{13}$

As a single negative charge on the M6P is sufficient to preserve the recognition phenomenon we decided to synthesize a series of isosteric or non isosteric carboxylate analogues of M6P to determine their binding affinities for the M6P/IGF2R.

\subsection{Synthesis of carboxylate analogues of M6P}

Two isosteric carboxylate analogues of M6P were prepared with slight modifications to the synthesis protocols previously reported. ${ }^{14}$ The new synthesis of these carboxylates began with the selective oxidation ${ }^{15}$ of the methyl 2,3,4,6-tetra- $O$-trimethylsilyl- $\alpha$-D-mannopyranoside ${ }^{16}$ using the Collins oxidative reagent $\left(\mathrm{CrO}_{3}\right.$-pyridine), scheme 1 . In this procedure, there are selective trimethylsilyl ether removal at 6-position and concomitantly oxidation of the intermediate alcohol to aldehyde. ${ }^{15}$ To the aldehyde, obtained in this one step procedure, was added the anion of triethyl phosphonoacetate to lead to the carboxylate $\mathbf{1}$ in $51 \%$. Synthetic intermediate 1 was readily converted to the desired deprotected carboxylate 2 by desilylation at 2,3,4-positions using the ceric ammonium nitrate (CAN) then saponification $(\mathrm{NaOH})$ of the ester moiety. The saturated carboxylate 3 was obtained by catalytic hydrogenation of a fraction of 2 . 

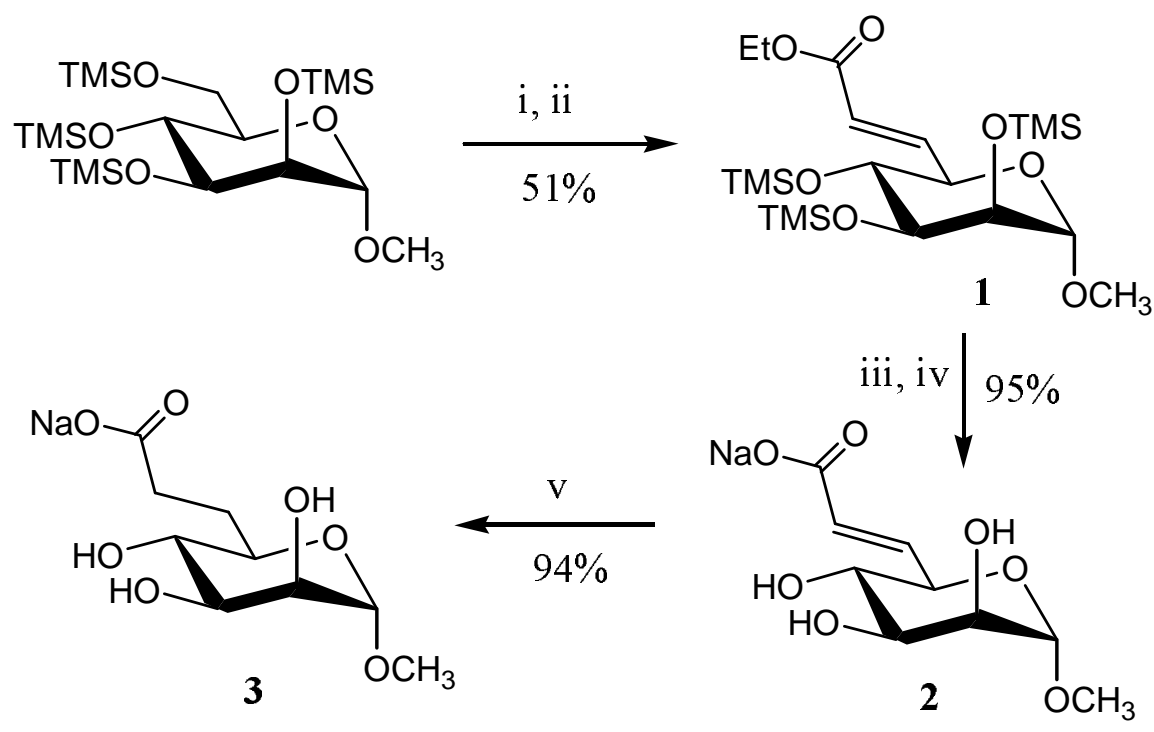

Scheme 1. Reagents and conditions : (i) $\mathrm{CrO}_{3} /$ pyridine, $\mathrm{CH}_{2} \mathrm{Cl}_{2}, 0{ }^{\circ} \mathrm{C}, 1 \mathrm{~h}$; (ii) $(\mathrm{EtO})_{2}(\mathrm{O}) \mathrm{P}-\mathrm{CH}_{2}-\mathrm{CO}_{2} \mathrm{Et}, \mathrm{NaH}, \mathrm{THF}, 10 \mathrm{~min}$; (iii) $\mathrm{CAN}, \mathrm{CH}_{3} \mathrm{CN} / \mathrm{H}_{2} \mathrm{O}(95 / 5)$, 15 min; (iv) $2 \mathrm{~N} \mathrm{NaOH}, 1 \mathrm{~h}$; (v) $\mathrm{H}_{2} / \mathrm{Pd} / \mathrm{C}, \mathrm{EtOH}, 4 \mathrm{~h}$.

The carboxylate 6, non isosteric analogue of M6P, was synthesized according to scheme 2. The anion of the methyl 2,3,4-tri- $O$-benzyl- $\alpha$-D-mannopyranoside ${ }^{17}$ reacted with the tertbutyl bromoacetate through a $\mathrm{S}_{\mathrm{N}} 2$ mechanism and the compound 4 was prepared in $74 \%$ yield in this manner. The target product 6 was obtained after deprotection of the carboxylate moiety (5) followed by the removal of the benzyl protective groups. It is to note that assays of reaction of the anion of the methyl 2,3,4-tri- $O$-benzyl- $\alpha$-D-mannopyranoside on the less hindered ethyl or methyl bromoacetates failed to give cleanly the ether oxide function at 6position since many by-products were observed. 

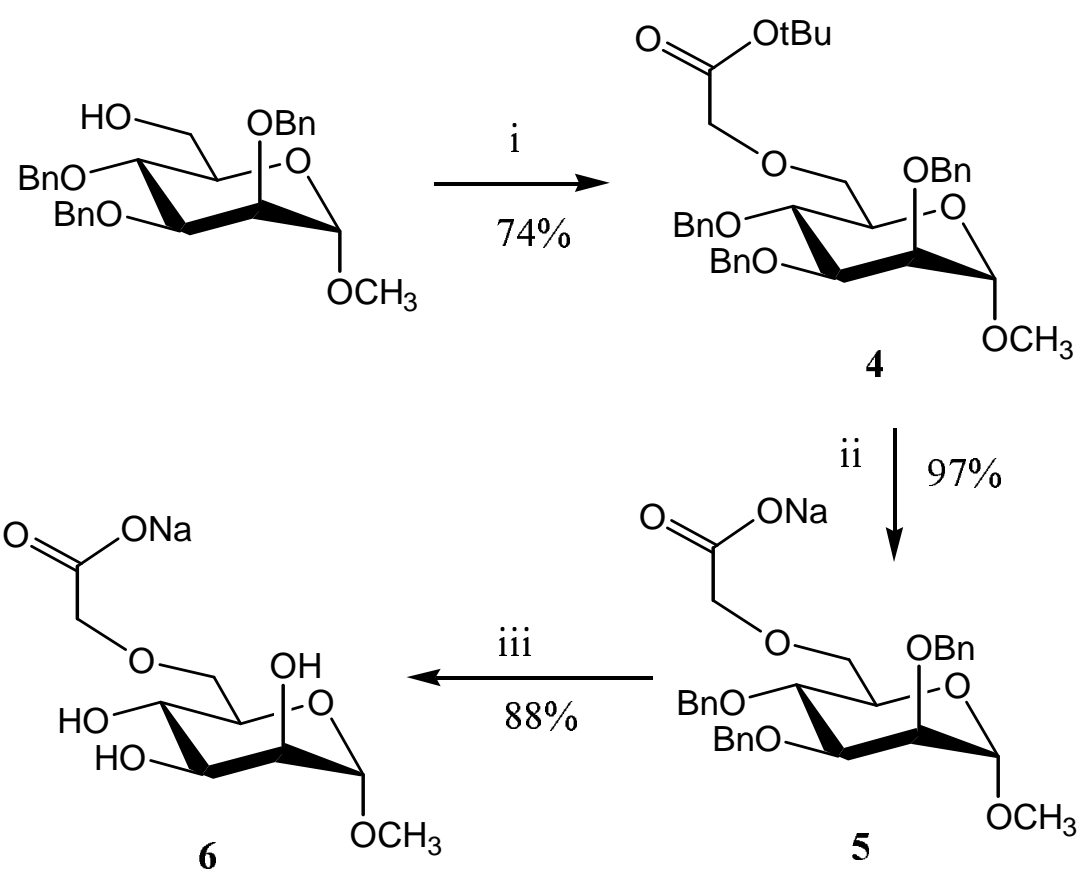

Scheme 2. Reagents and conditions : (i) NaH, DMF, $30 \mathrm{~min}$, then $\mathrm{tBuO}_{2} \mathrm{C}-\mathrm{CH}_{2} \mathrm{Br}, 3 \mathrm{~h}$; (ii) TFA, $\mathrm{Et}_{3} \mathrm{SiH}, \mathrm{CH}_{2} \mathrm{Cl}_{2}, 15 \mathrm{~h}$, then DOWEX Na${ }^{+}$; (iii) $\mathrm{H}_{2} / \mathrm{Pd} / \mathrm{C}, \mathrm{EtOH}, 4 \mathrm{~h}$.

\subsection{Synthesis of a mannose 6-malonate derivative.}

The key step for the synthesis of the malonate 9 , scheme 3 , was the reaction of the anion of dimethyl malonate with the methyl 2,3,4-tri- $O$-benzyl-6- $O$-trifluoromethylsulfonyl- $\alpha$-Dmannopyranoside ${ }^{18}$ while the less reactive tosylate or mesylate at C-6 of the methyl 2,3,4-tri$O$-benzyl- $\alpha$-D-mannopyranoside were not displaced under the same conditions of reaction. The malonate 7 , thus obtained, underwent saponification (8) and subsequent hydrogenation to afford the desired product 9. 

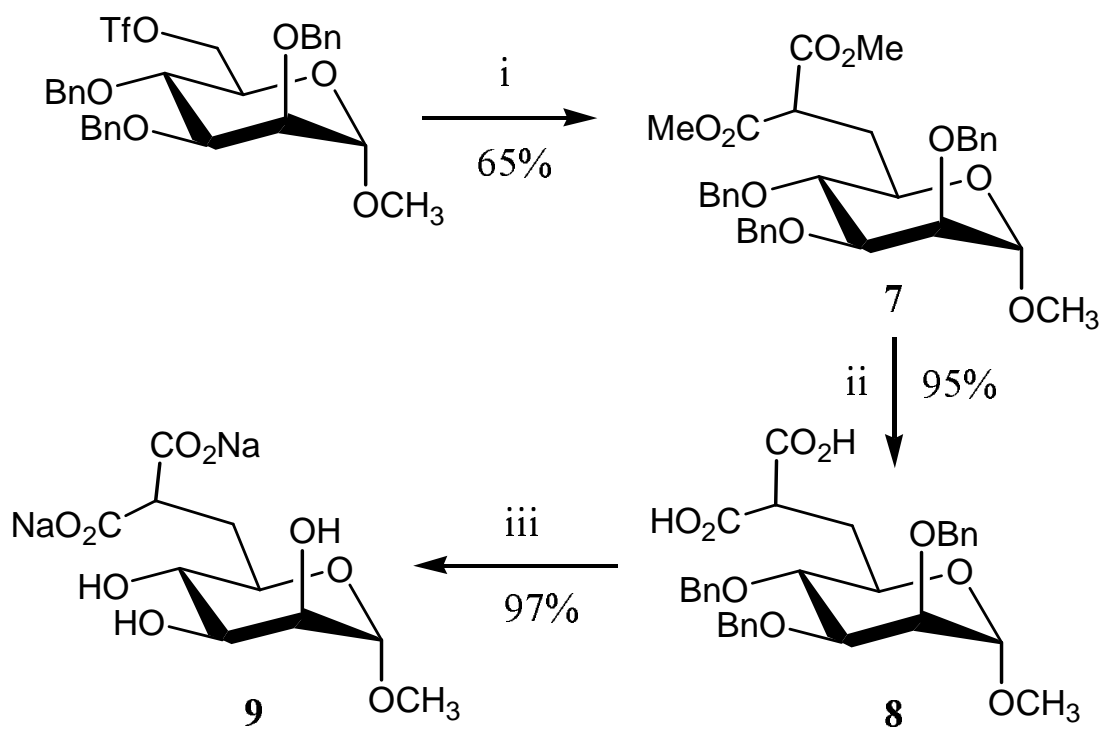

Scheme 3. Reagents and conditions: (i) $\left(\mathrm{MeO}_{2} \mathrm{C}\right)_{2} \mathrm{CHNa}$, THF, $15 \mathrm{~h}$ reflux; (ii) $4 \mathrm{~N} \mathrm{NaOH}, \mathrm{THF} / \mathrm{H}_{2} \mathrm{O}(4 / 6), 35 \mathrm{~min}$ ))), then $5 \mathrm{~N} \mathrm{HCl}$; (iii) $1 . \mathrm{H}_{2} / \mathrm{Pd} / \mathrm{C}$, EtOH/AcOEt (7/3), $4 \mathrm{~h}$, then DOWEX Na ${ }^{+}$.

\subsection{Biological evaluation}

The binding assays of the M6P analogues were performed using biotinylated M6P/IGF2R (M6P/IGF2R $b$ ). Briefly, the M6P/IGF2R, purified on a phosphomannan-sepharose affinity column $^{19}$, was biotinylated ${ }^{20}$ by $\mathrm{N}$-hydroxysuccinimid biotin. The binding of the M6P/IGF2R $b$ to pentamannose 6-phosphate (PMP) previously adsorbed to a microtiter plate, was displaced by increasing concentrations of the analogues. The bound M6P/IGF2R $b$ was then determined using the couple streptavidin/peroxidase and OPD substrate by optical densities measurements as described in Experimental procedures. In preliminary experiments the method was standardized by the determination of the maximal concentration of PMP adsorbed to the microtiter plate and to the M6P/IGF2R $b$ concentration required to saturate the adsorbed PMP (Figure 1). 

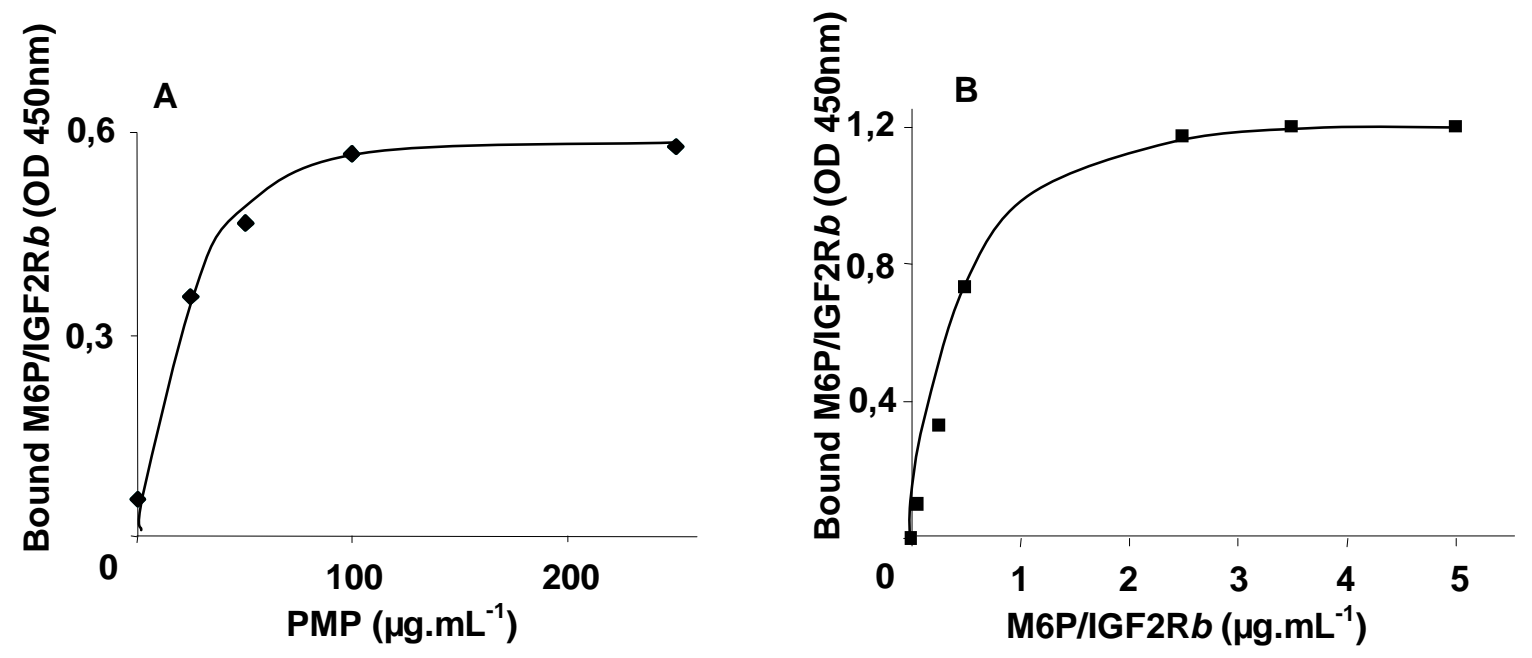

Figure 1. Determination of PMP adsorption in microtiter wells and M6P/IGF2R $b$ binding. A. The binding of $2.5 \mu \mathrm{g} \cdot \mathrm{mL}^{-1} \mathrm{M} 6 \mathrm{P} / \mathrm{IGF} 2 \mathrm{R} b$ to increasing concentrations of PMP adsorbed on microtiter plate was evaluated using the streptavidine/peroxidase procedure.

B. The retention of various concentrations of M6P/IGF2R $b\left(0\right.$ to $\left.5 \mu \mathrm{g} \cdot \mathrm{mL}^{-1}\right)$ to the microplate previously saturated with $100 \mu \mathrm{g} \cdot \mathrm{mL}^{-1} \mathrm{PMP}$ was determined after overnight incubation at 4 ${ }^{\circ} \mathrm{C}$.

From these measurements of the receptor binding in the presence of increasing concentrations of analogues 2, 3, 6 or 9, were drawn dose-inhibition curves (Figure 2) from which were determined the $\mathrm{IC}_{50}$ values reported in table 1. 
A

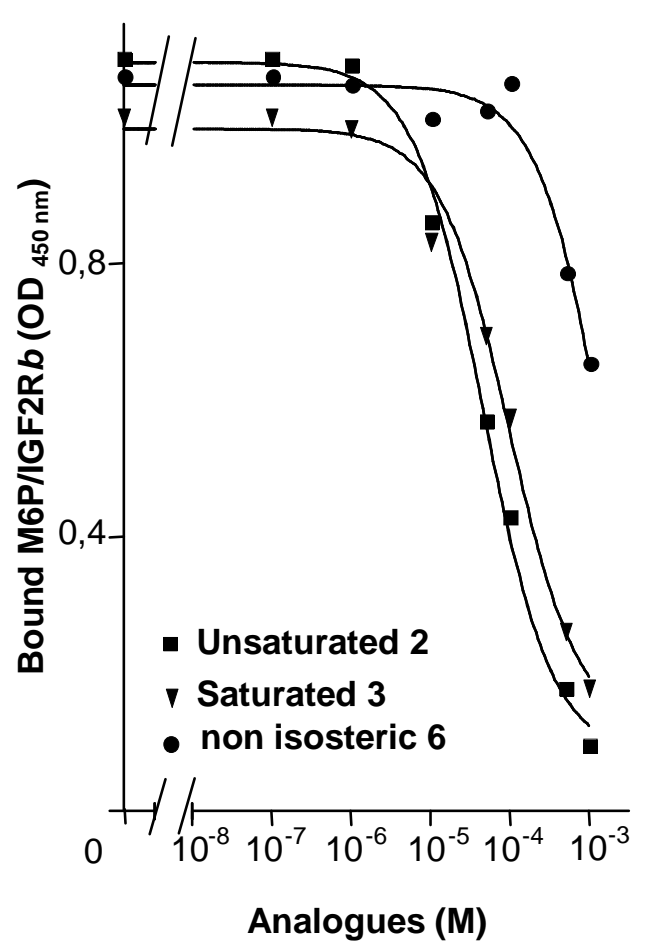

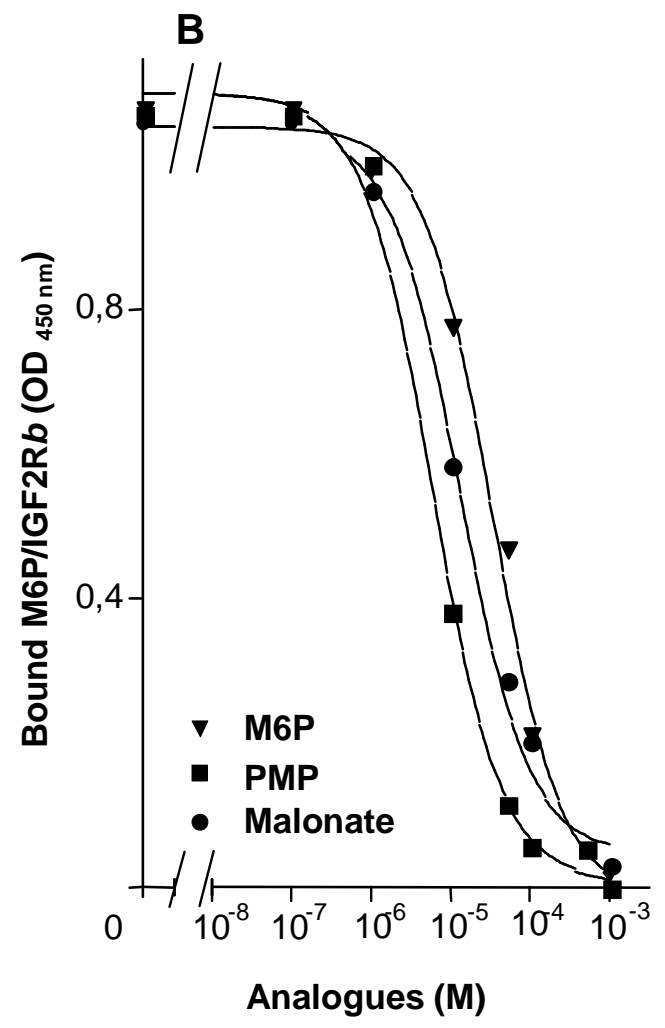

Figure 2. Displacement of PMP from M6P/IGF2R $b$ by M6P analogues.

First analysis of the data given in table 1 shows that M6P presents $\mathrm{IC}_{50}$ values in good accordance with those reported in the literature. ${ }^{21}$

Table 1. Binding affinities for M6P/IGF2R.

\begin{tabular}{|c|c|c|c|c|c|}
\hline Compound & $\mathrm{IC}_{50}(\mathrm{M})$ & $\mathrm{RBA}$ & Compound & $\mathrm{IC}_{50}(\mathrm{M})$ & $\mathrm{RBA}$ \\
\hline M6P & $2.310^{-5} \pm 110^{-5}$ & 1.0 & PMP & $5.610^{-6} \pm 0.710^{-6}$ & 4.1 \\
\hline $\mathbf{2}$ & $3.910^{-5} \pm 1.110^{-5}$ & 0.6 & $\mathbf{6}$ & $>110^{-3}$ & $\mathrm{na}^{*}$ \\
\hline $\mathbf{3}$ & $7.410^{-5} \pm 1.910^{-5}$ & 0.3 & $\mathbf{9}$ & $1.210^{-5} \pm 0.310^{-5}$ & 1.9 \\
\hline
\end{tabular}

Relative Binding Affinity $=\mathrm{RBA}=\mathrm{IC}_{50 \text { (M6P) }} / \mathrm{IC}_{50}$ (Analogue). ${ }^{*}$ na $=$ not applicable.

The unsaturated isosteric analogue 2 binds to M6P/IGF2R $b$ as well as M6P while the saturated isosteric analogue $\mathbf{3}$ binds to the receptor with a slightly weaker affinity than does M6P. This is a confirmation of the results previously obtained by elution of the receptor from PMP affinity columns. ${ }^{14}$ Indeed, it was demonstrated that $2.5 \mathrm{mM}$ of the conjugated derivative 2 eluted the M6P/IGF2R, retained on phophomannan sepharose column, as the M6P whereas 3 allowed the elution of the receptor at a higher concentration $(5 \mathrm{mM})$. To explain this difference in binding affinity, it is presumed that the geometry of the double bond 
in 2 leads to greater interaction with the M6P-binding sites of the M6P/IGF2R, in comparison with the single bond in 3 . On the other hand, the non isosteric derivative 6 is weakly recognized by the M6P/IGF2R $b$. We suppose that 6 does not match exactly the M6P-binding sites of the receptor because the distance between the negative charge and the pyranose ring in $\mathbf{6}$ is not in the same range as that in the M6P. Indeed, this distance in $\mathbf{6}$, by comparison to the isosteric M6P analogue 3, is lengthened by an oxygen atom in the middle of the lateral carbon chain and this lengthening of the lateral chain probably impairs the binding affinity. A high binding affinity was obtained with the malonate 9 which is as well recognized by the M6P/IGF2R $b$ as the M6P itself. This last result does not correlate exactly with $\mathrm{IC}_{50}$ values determined by Berkowitz et $a .^{21}$ However, their binding test followed a procedure in which the M6P/IGF2R was covalently bound to a Sepharose resin, while in our case the M6P/IGF2R $b$ was not bound to a support. This difference could perhaps explain the differences observed between the binding affinities.

The stability after a 2 day-incubation in human serum at $37{ }^{\circ} \mathrm{C}$ of the analogues 2,3 and 9 was compared to M6P. Figure 3 showed that the analogues 2, 3 and 9 were recognized similarly along time, while M6P shown a decreased affinity for the receptor after 2 dayincubation in serum. Moreover, a 6h-incubation appeared sufficient to decrease the binding of M6P by $32 \%$ (Figure 3 insert). This indicates that, in opposite to M6P which is rapidly degraded by hydrolases, and particularly phosphatases, all the analogues tested are stable after a long exposure in human serum. 


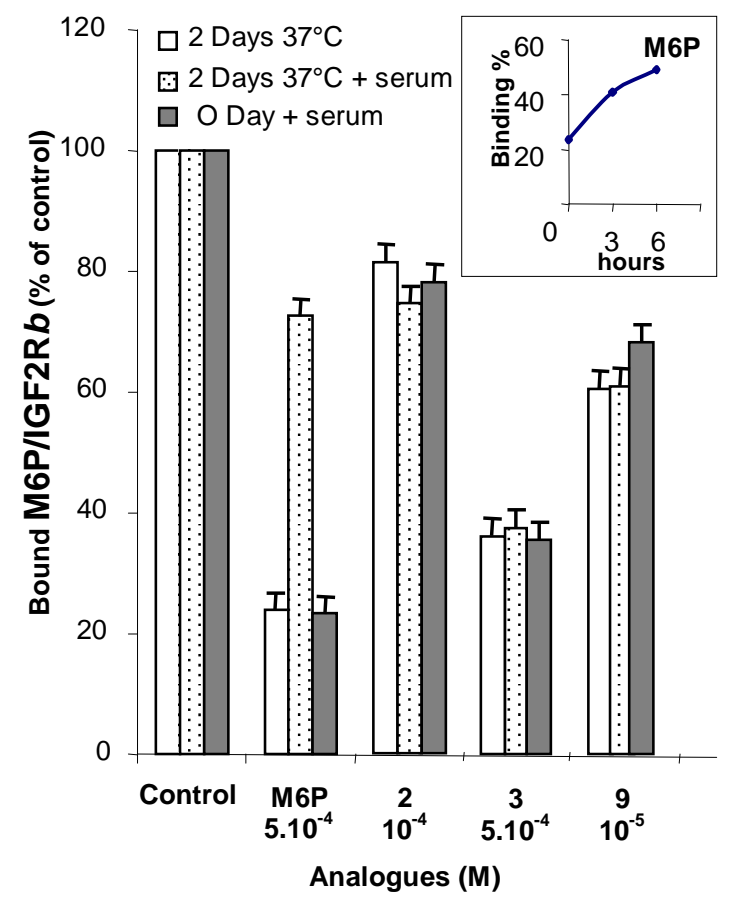

Figure 3: Stability of the analogues in human serum.

The binding of M6P/IGF2R to PMP was measured in the absence (control) or in the presence of the analogues as described in Experimental procedures. The competition by the analogues was performed in the absence or presence of serum either directly ( 0 day + serum $)$ or after incubation for 2 days at $37{ }^{\circ} \mathrm{C}$. The insert indicates the competition by $510^{-4} \mathrm{M}$ M6P incubated for the indicated times at $37^{\circ} \mathrm{C}$ in the presence of human serum.

Moreover, we evaluated the cytotoxicity of the analogues 2, 3 and 9 on MCF7 or MDA-MB231 human breast cancer cell lines (Figure 4). After 4 days in the culture medium, all the compounds appeared non cytotoxic even at high concentration $\left(10^{-4} \mathrm{M}\right)$ on these two cell lines. 


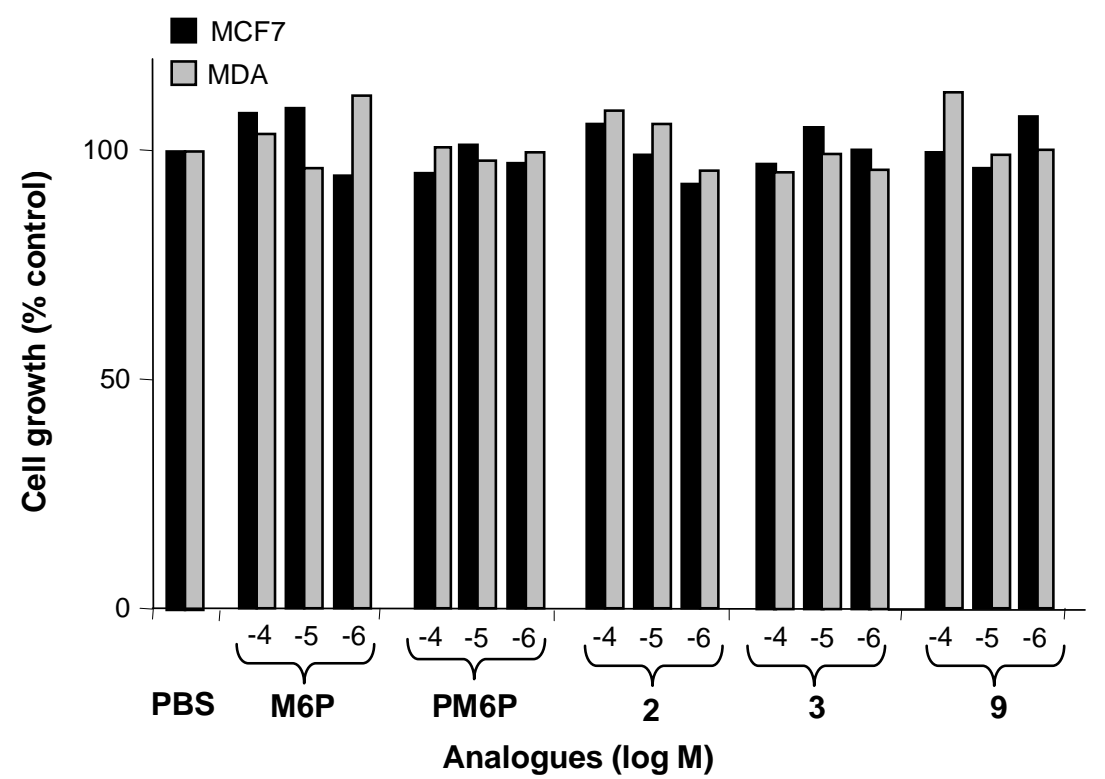

Figure 4. Absence of cytotoxicity of the analogues in human cell lines. MDA-MB-231 and MCF7 cells were grown for 4 days in the presence of the indicated concentrations of analogues and the cell growth was evaluated in triplicate as described in Experimental procedures. Standard deviations of the means were always inferior to $5 \%$.

\section{Conclusion}

This study underlines the fact that a single negative charge on an isosteric analogue derivative of M6P is sufficient to preserve the recognition by the M6P/IGF2R. The affinity of the conjugated analogue 2 was in the same order than for M6P, while the saturated derivative 3 was slightly less well recognized by the M6P/IGF2R. Similarly to M6P, the malonate 9 can exist under a dianionic state at physiological $\mathrm{pH}$. This could explain the very good affinity of 9 for the receptor. Moreover, the two carboxylic acid functions at the terminal carbon chain of 9 did not seem to impair the recognition phenomenon by steric hindrance.

Therefore compounds 2, 3 and $\mathbf{9}$ that present very good affinities for M6P/IGF2R could be good candidates for the treatment of various diseases. For instance, they could be used to improve wound healing which is known to be favoured by M6P delivery on the site of wounds. $^{22}$ Another application could be in enzyme replacement therapy, especially in lysosomal diseases. In fact the source for recombinant enzyme synthesis is restricted to mammalian cells by the fact that other organisms do not possess the M6P recognition pathway. The coupling of stable M6P analogues could permit the use of other sources of recombinant enzyme such as bacteria or insect cells and to increase the targeting efficiency of the infused enzymes to tissues enriched in M6P receptors. 


\section{Experimental procedures}

4.1. General Aspects: All solvents were dried prior to use according to standard methods. ${ }^{23}$ Analytical TLC were performed using aluminum-coated TLC plates 60-F 254 (Merck). - Plates were developed with (1) UV light (254 nm), and (2) immersion in a $10 \% \mathrm{H}_{2} \mathrm{SO}_{4} / \mathrm{EtOH}$ solution - Silica gel column chromatography was performed with silica gel 60A (Carlo Erba). - Optical rotations were measured at the sodium D-line with a Perkin-Elmer-241 polarimeter. -Electron ionization mass spectra $(30 \mathrm{eV})$ were recorded in positive or negative mode on a Waters MicroMass ZQ $-{ }^{1} \mathrm{H}$ NMR Spectra were recorded on a Brüker DRX 400 $(400 \mathrm{MHz})$, at $25{ }^{\circ} \mathrm{C}$. Chemical shifts $(\delta)$ are given in ppm and referenced using residual solvent signals (7.24 ppm for $\mathrm{CHCl}_{3}$ and $4.79 \mathrm{ppm}$ for HOD). The following abbreviations were used to explain the signal multiplicities or characteristics: s (singlet), d (doublet), dd (double doublet), ddd (double double doublet), $\mathrm{t}$ (triplet), $\mathrm{td}$ (triplet doublet), q (quartet), $\mathrm{m}$ (multiplet). $-{ }^{13} \mathrm{C}$ NMR Spectra were recorded on a Brüker DRX $400(100.6 \mathrm{MHz})$. Chemical shifts $(\delta)$ are given in ppm relative to TMS as an external reference. - The pentamannose 6phosphate (PMP) was functionalized with $\beta$-( $p$-aminophenyl)ethylamine, then reduced with sodium tetrahydroborate, and finally coupled on $\mathrm{CNBr}$ activated Sepharose leading to phosphomannan Sepharose. ${ }^{24}$ - Buffers and solutions used in the purification of M6P/IGF2R and in the ELISA assays were : buffer A (50 mM imidazol pH $7 ; 150 \mathrm{mM} \mathrm{NaCl} ; 5 \mathrm{mM} \beta$ glycerophosphate ; 0.05\% Triton x-100 (w/v)); PBS (1.9 mM NaH $\mathrm{PO}_{4}, 8.1 \mathrm{mM} \mathrm{Na}_{2} \mathrm{PO}_{4}$ and $154 \mathrm{mM} \mathrm{NaCl}, \mathrm{pH} 7.4)$; carbonate buffer (0.1 $\left.\mathrm{M} \mathrm{NaHCO}_{3} / \mathrm{Na}_{2} \mathrm{CO}_{3}, \mathrm{pH} 9.6\right)$; washing buffer (2 mg. $\mathrm{mL}^{-1}$ gelatine in PBS); OPD (o-phenylenediamine $1 \mathrm{mg} \cdot \mathrm{mL}^{-1}$ in citrate buffer $\mathrm{pH} 5.0$ and 1 $\mu \mathrm{L} 30 \% \mathrm{H}_{2} \mathrm{O}_{2}$.)

\subsection{Ethyl (methyl (E)-6,7-dideoxy-2,3,4-tri- $O$-trimethylsilyl- $\alpha$-D-manno-oct-6- enopyranosid)uronate 1}

Finely ground and thorougly dried chromium (VI) oxide $(2.5 \mathrm{~g}, 24.88 \mathrm{mmol})$ were suspended in dry dichloromethane $(80 \mathrm{~mL})$ containing dry pyridine $(4 \mathrm{~mL})$. The mixture was stirred at room temperature for $30 \mathrm{~min}$. Then, the mixture was cooled at $0{ }^{\circ} \mathrm{C}$ and methyl 2,3,4,6-tetra- $O$-trimethylsilyl- $\alpha$-D-mannopyranoside ${ }^{16}(2 \mathrm{~g}, 4.15 \mathrm{mmol})$ dissolved in dry dichloromethane $(6 \mathrm{~mL})$ was added. After $1 \mathrm{~h}$ the mixture was filtered over silica gel to 
remove insoluble chromium coumpounds. The filtrate was concentrated in vacuo affording the aldehyde $(1.24 \mathrm{~g}, 73 \%)$ that was used for the next step without further purification.

To a suspension of $\mathrm{NaH}(98 \%, 204 \mathrm{mg}, 8.33 \mathrm{mmol})$ in THF $(2 \mathrm{~mL})$ was added triethyl phosphonoacetate $(2 \mathrm{~mL}, 9.99 \mathrm{mmol})$. Reaction was stirred for $30 \mathrm{~min}$ at room temperature, then a solution of the crude aldehyde in THF $(10 \mathrm{~mL})$ was added dropwise. The reaction was monitored by TLC (light petroleum/Et ${ }_{2} \mathrm{O} 9 / 1 \mathrm{v} / \mathrm{v}$ ) and stirred for $10 \mathrm{~min}$ before concentrating under reduced pressure. The residue was diluted with $\mathrm{CH}_{2} \mathrm{Cl}_{2}$ and the organic layer washed with brine, dried $\left(\mathrm{Na}_{2} \mathrm{SO}_{4}\right)$, filtered and concentrated under reduced pressure. The residue was purified by silica gel column chromatography (light petroleum/ $\mathrm{Et}_{2} \mathrm{O} 95 / 5$ then $9 / 1 \mathrm{v} / \mathrm{v}$ ) to afford 1 (1.4 g, 70\%) as a yellow oil. The spectroscopic data were in accordance with literature. $^{14}$

\subsection{Sodium (methyl (E)-6,7-dideoxy- $\alpha$-D-manno-oct-6-enopyranosid)uronate 2}

CAN (298 mg, $0.54 \mathrm{mmol})$ was added to a solution of $\mathbf{1}(1.3 \mathrm{~g}, 2.72 \mathrm{mmol})$ dissolved in a mixture of $\left(\mathrm{CH}_{3} \mathrm{CN} / \mathrm{H}_{2} \mathrm{O} 95 / 5 \mathrm{v} / \mathrm{v}, 15 \mathrm{~mL}\right)$. The reaction was monitored by TLC $(\mathrm{AcOEt} / \mathrm{MeOH} 92 / 8 \mathrm{v} / \mathrm{v})$. After $20 \mathrm{~min}$ stirring at room temperature, the mixture was diluted with $\mathrm{CH}_{2} \mathrm{Cl}_{2}$. The organic layer was washed with $\mathrm{H}_{2} \mathrm{O}$, brine, dried $\left(\mathrm{Na}_{2} \mathrm{SO}_{4}\right)$, filtered and concentrated under reduced pressure. Ethyl (methyl (E)-6,7-dideoxy- $\alpha$-D-manno-oct-6enopyranoside)uronate (712 mg, quantitative) was obtained pure as a colorless oil. The spectroscopic data were in accordance with literature. ${ }^{14}$

Ethyl (methyl (E)-6,7-dideoxy- $\alpha$-D-manno-oct-6-enopyranosid)uronate (700 mg, $2.67 \mathrm{mmol}$ ) was dissolved in $2 \mathrm{~N} \mathrm{NaOH}(20 \mathrm{~mL})$ at $0{ }^{\circ} \mathrm{C}$. The mixture was stirred for $1 \mathrm{~h}$ and neutralized with $0.5 \mathrm{~N} \mathrm{HCl}$ until pH 7. Then, ion exchange resin (Dowex $50 \mathrm{WX} 2, \mathrm{Na}^{+}$form, $20 \mathrm{~g}$ ) was added. After stirring at room temperature for $2 \mathrm{~h}$, the resin was filtered off and washed with $\mathrm{H}_{2} \mathrm{O}(100 \mathrm{~mL})$. The filtrate was freeze dried from $\mathrm{H}_{2} \mathrm{O}$ affording $2(650 \mathrm{mg}, 95 \%)$ as a white foam. The spectroscopic data were in accordance with literature. ${ }^{14}$

\subsection{Sodium (methyl 6,7-dideoxy- $\alpha$-D-manno-octopyranosid)uronate 3}

A solution of $2(600 \mathrm{mg}, 2.34 \mathrm{mmol})$ in $\mathrm{EtOH}(20 \mathrm{~mL})$ was stirred vigorously under $\mathrm{H}_{2(\mathrm{~g})}$ for $4 \mathrm{~h}$ in the presence of $10 \% \mathrm{Pd}-\mathrm{C}$ as catalyst. The mixture was filtered under celite, then 
washed with EtOH $(100 \mathrm{~mL})$ and concentrated. The crude product was purified by column chromatography on RP-18 silica gel using water as eluent. After freeze drying, 3 (568 mg, $94 \%$ ) was obtained as a white foam. The spectroscopic data were in accordance with literature. $^{14}$

\subsection{Methyl 2,3,4-tri- $O$-benzyl-6- $O$-(2-tert-butyloxy-2oxoethyl)- $\alpha$-D-mannopyranoside 4}

To a solution of methyl 2,3,4-tri- $O$-benzyl- $\alpha$-D-mannopyranoside ${ }^{17}(581 \mathrm{mg}, 1.25 \mathrm{mmol})$ in dry DMF (5 mL), NaH $(60 \%, 200 \mathrm{mg})$ was added under argon. The reaction was stirred at room temperature for $3 \mathrm{~h}$. Then, tert-butyl bromoacetate $(1.82 \mathrm{~mL}, 12.32 \mathrm{mmol})$ was added dropwise at room temperature and the mixture was stirred for $3 \mathrm{~h}$. The solution was diluted with $\mathrm{CH}_{2} \mathrm{Cl}_{2}(100 \mathrm{~mL})$ and the organic layer was washed with brine $(100 \mathrm{~mL})$, dried $\left(\mathrm{Na}_{2} \mathrm{SO}_{4}\right)$, filtered, concentrated and purified by silica gel column chromatography (light petroleum/ $/ \mathrm{Et}_{2} \mathrm{O} 9 / 1$ then $8 / 2 \mathrm{v} / \mathrm{v}$ ) to give $4\left(537 \mathrm{mg}, 74 \%\right.$ ) as a colorless oil. $R_{f} 0.55$ (light petroleum/AcOEt 8/2). $[\alpha]_{\mathrm{D}}{ }^{20}+29.36\left(c 1.1 / \mathrm{CHCl}_{3}\right) .{ }^{1} \mathrm{H} \mathrm{NMR}\left(\mathrm{CDCl}_{3}\right), \delta: 1.32(\mathrm{~s}, 9 \mathrm{H}$, $\left.3 \mathrm{CH}_{3}\right) ; 3.17\left(\mathrm{~s}, 3 \mathrm{H}, \mathrm{O} \mathrm{CH}_{3}\right) ; 3.60(\mathrm{~m}, 1 \mathrm{H}, \mathrm{H}-5) ; 3.67\left(\mathrm{~d}, 1 \mathrm{H}, J_{2-3}=2.3 \mathrm{~Hz}, \mathrm{H}-2\right) ; 3.70(\mathrm{~d}, 2 \mathrm{H}$, $J_{\mathrm{CH} 2-5}=3.7 \mathrm{~Hz}, \mathrm{H}-6$ and 6'); $3.78\left(\mathrm{dd}, 1 \mathrm{H}, J_{3-4}=9.3 \mathrm{~Hz}, \mathrm{H}-3\right) ; 3.83\left(\mathrm{t}, 1 \mathrm{H}, J_{4-5}=9.3 \mathrm{~Hz}, \mathrm{H}-\right.$ 4); $3.93\left(\mathrm{~s}, 2 \mathrm{H}, \mathrm{H}-7\right.$ and $\left.7^{\prime}\right) ; 4.48-4.63\left(\mathrm{~m}, 5 \mathrm{H}, \mathrm{CH}_{2} \mathrm{Ph}\right) ; 4.59$ (s, $\left.1 \mathrm{H}, \mathrm{H}-1\right) ; 4.83\left(\mathrm{~d}, 1 \mathrm{H}, J_{\mathrm{a}-\mathrm{b}}=\right.$ $\left.10.8 \mathrm{~Hz}, \mathrm{CH}_{2} \mathrm{Ph}\right) ; 7.10-7.24$ (m, 15H, 15H-ar). ${ }^{13} \mathrm{C} \mathrm{NMR}\left(\mathrm{CDCl}_{3}\right), \delta: 28.32,28.43,28.55$ $\left(3 \mathrm{CH}_{3}\right) ; 55.18\left(\mathrm{OCH}_{3}\right) ; 69.72(\mathrm{C}-7) ; 70.99(\mathrm{C}-6) ; 72.20(\mathrm{C}-5) ; 72.54,73.11\left(2 \mathrm{CH}_{2} \mathrm{Ph}\right) ; 74.98$

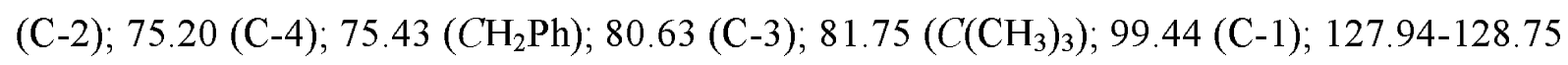
(15CH-aro); 138.77, 138.98, $139.07\left(3 \mathrm{C}^{\mathrm{IV}}\right.$-aro); $170.05(\mathrm{CO}) . \mathrm{MS} \mathrm{ESI}^{+}, m / z: 601[\mathrm{M}+\mathrm{Na}]^{+}$.

\subsection{Methyl 2,3,4-tri- $O$-benzyl-6- $O$-(carboxymethyl)- $\alpha$-D-mannopyranoside sodium salt 5}

To a solution of $4(532 \mathrm{mg}, 0.92 \mathrm{mmol})$ and trifluoroacetic acid $(918 \mu \mathrm{L}, 11.92 \mathrm{mmol})$ in $\mathrm{CH}_{2} \mathrm{Cl}_{2}(2 \mathrm{~mL})$, triethylsilane $(366 \mu \mathrm{L}, 2.29 \mathrm{mmol})$ was added under argon atmosphere. The reaction was stirred at room temperature for $15 \mathrm{~h}$. After evaporation of solvents, the residue was dissolved with water $(50 \mathrm{~mL})$ and cation exchange resin in the $\mathrm{Na}^{+}$form was added. After stirring at room temperature for $1 \mathrm{~h}$, the resin was filtered off and washed several times with water. The aqueous phase was lyophilized to afford $\mathbf{5}(466 \mathrm{mg}, 97 \%)$ as a white solid. $R_{f} 0.13$ (light petroleum /AcOEt 5/5). $[\alpha]_{\mathrm{D}}{ }^{20}-2.99\left(c 1.8 / \mathrm{CHCl}_{3}\right) .{ }^{1} \mathrm{H} \mathrm{NMR}\left(\mathrm{CDCl}_{3}\right), \delta$ : $3.13\left(\mathrm{~s}, 3 \mathrm{H}, \mathrm{CH}_{3} \mathrm{O}\right) ; 3.40-3.54(\mathrm{~m}, 3 \mathrm{H}, \mathrm{H}-5, \mathrm{H}-6$ and 6$) ; 3.70\left(\mathrm{dd}, 1 \mathrm{H}, J_{2-1}=1.2 \mathrm{~Hz}, J_{2-3}=2.5\right.$ $\mathrm{Hz}, \mathrm{H}-2) ; 3.62-3.73\left(\mathrm{~m}, 2 \mathrm{H}, \mathrm{H}-7\right.$ and 7'); $3.77\left(\mathrm{dd}, 1 \mathrm{H}, J_{3-4}=9.5 \mathrm{~Hz}, \mathrm{H}-3\right) ; 3.97\left(\mathrm{t}, 1 \mathrm{H}, J_{4-5}=\right.$ $9.5 \mathrm{~Hz}, \mathrm{H}-4) ; 4.48\left(\mathrm{~s}, 2 \mathrm{H}, \mathrm{CH}_{2} \mathrm{Ph}\right) ; 4.53\left(\mathrm{~d}, 1 \mathrm{H}, J_{\mathrm{a}-\mathrm{b}}=11,5 \mathrm{~Hz}, \mathrm{CH}_{2} \mathrm{Ph}\right) ; 4.64(\mathrm{~d}, 1 \mathrm{H}, \mathrm{H}-1)$; 
$4.73\left(\mathrm{~d}, 1 \mathrm{H}, J_{\mathrm{a}^{\prime}-\mathrm{b}^{\prime}}=12.8 \mathrm{~Hz}, \mathrm{CH}_{2} \mathrm{Ph}\right) ; 4.81\left(\mathrm{~d}, 2 \mathrm{H}, 2 \mathrm{CH}_{2} \mathrm{Ph}\right) ; 7.14-7.29(\mathrm{~m}, 15 \mathrm{H}, 15 \mathrm{H}-\mathrm{ar}) .{ }^{13} \mathrm{C}$ NMR $\left(\mathrm{CDCl}_{3}\right), \delta: 55.58\left(\mathrm{OCH}_{3}\right) ; 67.96$ (C-7); 69.06 (C-6); 70.51 (C-5); 72.34 (C-2); 72.50 $\left(\mathrm{CH}_{2} \mathrm{Ph}\right) ; 73.30(\mathrm{C}-4) ; 73.45\left(\mathrm{CH}_{2} \mathrm{Ph}\right) ; 75.52\left(\mathrm{CH}_{2} \mathrm{Ph}\right) ; 80.50(\mathrm{C}-3) ; 100.25(\mathrm{C}-1)$; 127.81 129.09 (15CH-aro); $137.54,138.39,138.56\left(3 \mathrm{C}^{\mathrm{IV}}\right.$-aro); $176.08(\mathrm{CO}) . \mathrm{MS} \mathrm{ESI}^{+}, m / z: 545.15$ $[\mathrm{M}+\mathrm{H}]^{+}$.

\subsection{Methyl 6-O-(carboxymethyl)- $\alpha$-D-mannopyranoside sodium salt 6}

To a solution of $5(87 \mathrm{mg}, 0.17 \mathrm{mmol})$ in $\mathrm{EtOH}(5 \mathrm{~mL})$ was added $150 \mathrm{mg}$ of $10 \% \mathrm{Pd} / \mathrm{C}$. After stirring under $\mathrm{H}_{2(\mathrm{~g})}$ for $4 \mathrm{~h}$, the mixture was filtered through Celite pad, then washed with EtOH $(100 \mathrm{~mL})$ and concentrated under vacuum. The crude product was purified by column chromatography on reversed phase $\left(\mathrm{RP}-18, \mathrm{H}_{2} \mathrm{O}\right)$. After lyophilization, 6 was obtained as a white powder $(37 \mathrm{mg}, 88 \%) . R_{f} 0.25\left(\mathrm{NH}_{4} \mathrm{OH} / \mathrm{H}_{2} \mathrm{O} / \mathrm{iPrOH} 1 / 1 / 8\right) .[\alpha]_{\mathrm{D}}{ }^{20}$ $+45.75\left(c 0.8 / \mathrm{D}_{2} \mathrm{O}\right) .{ }^{1} \mathrm{H}$ NMR $\left.\left(\mathrm{D}_{2} \mathrm{O}\right), \delta: 3,29(\mathrm{~s}, 3 \mathrm{H}, \mathrm{O} \mathrm{CH})_{3}\right) ; 3,61-3,81(\mathrm{~m}, 6 \mathrm{H}, \mathrm{H}-2,3,4,5$, 6); 4,10 (s, 2H, CH $\left.\mathrm{CH}_{2} \mathrm{O}\right) ; 4,64(\mathrm{~s}, 1 \mathrm{H}, \mathrm{H}-1) ;{ }^{13} \mathrm{C} \mathrm{NMR}\left(\mathrm{D}_{2} \mathrm{O}\right), \delta: 54.85\left(\mathrm{OCH}_{3}\right) ; 68.23(\mathrm{C}-7)$; 69.91 (C-6); 66.57, 69.82, 70.35, 71.13 (C-2,3,4,5); 100.94 (C-1); 175.72 (CO).

$\mathrm{MS} \mathrm{ESI}^{-}, m / z: 251.20[\mathrm{M}-\mathrm{Na}]^{-}$.

\subsection{Methyl (methyl 2,3,4-tri- $O$-benzyl-6,7-dideoxy-7-(methoxycarbonyl)- $\alpha$-D-manno- octopyranosid)uronate 7}

To a solution of dimethyl malonate $(0.66 \mathrm{~g}, 5.0 \mathrm{mmol})$ in THF $(15 \mathrm{~mL})$, sodium hydride $(0.1$ g, $2.5 \mathrm{mmol}$ ) was added. The mixture was stirred under nitrogen for $30 \mathrm{~min}$, then a solution of methyl 2,3,4-tri- $O$-benzyl-6- $O$-trifluoromethanesulfonyl- $\alpha$-D-mannopyranoside ${ }^{18}(1.14 \mathrm{~g}$, $1.92 \mathrm{mmol})$ in THF (4 mL) was added dropwise. The mixture was refluxed for $15 \mathrm{~h}$, allowed to cool at room temperature, quenched with saturated ammonium chloride and extracted with ether. The organic layer was washed with brine, dried, filtered and concentrated under reduced pressure. The residue was purified by silica gel column chromatography (light petroleum/ $\mathrm{Et}_{2} \mathrm{O} 8 / 2$ then $\left.7 / 3 \mathrm{v} / \mathrm{v}\right)$ affording $7(722 \mathrm{mg}, 65 \%)$ as a colorless oil. $R_{f} 0.59$ $\left(\mathrm{Et}_{2} \mathrm{O} /\right.$ light petroleum 6/4). $[\alpha]_{\mathrm{D}}{ }^{20}+36.4\left(c 1.29 / \mathrm{CHCl}_{3}\right) .{ }^{1} \mathrm{H} \mathrm{NMR}\left(\mathrm{CDCl}_{3}\right), \delta: 2.04$ (ddd, $\left.1 \mathrm{H}, J_{6^{\prime}-5}=9.9 \mathrm{~Hz}, J_{6^{\prime}-6}=14.0 \mathrm{~Hz}, J_{6^{\prime}-7}=4.7 \mathrm{~Hz}, \mathrm{H}-6^{\prime}\right) ; 2.50\left(\mathrm{ddd}, 1 \mathrm{H}, J_{6-5}=2.4 \mathrm{~Hz}, J_{6-7}=10.7\right.$ $\mathrm{Hz}, \mathrm{H}-6) ; 3.19\left(\mathrm{~s}, 3 \mathrm{H}, \mathrm{OCH}_{3}\right) ; 3.47\left(\mathrm{td}, 1 \mathrm{H}, J_{5-4}=9.9 \mathrm{~Hz}, \mathrm{H}-5\right) ; 3.57-3.68(\mathrm{~m}, 3 \mathrm{H}, \mathrm{H}-2,4$ et 7); 3.63 et $3.64\left(2 \mathrm{~s}, 6 \mathrm{H}, 2 \mathrm{OCH}_{3}\right) ; 3.76\left(\mathrm{dd}, 1 \mathrm{H}, J_{3-2}=3.0 \mathrm{~Hz}, J_{3-4}=9.6 \mathrm{~Hz}, \mathrm{H}-3\right) ; 4.51(\mathrm{~s}, 2 \mathrm{H}$, $\left.\mathrm{CH}_{2} \mathrm{Ph}\right) ; 4.54\left(\mathrm{~d}, 1 \mathrm{H}, J_{1-2}=1.5 \mathrm{~Hz}, \mathrm{H}-1\right) ; 4.58\left(\mathrm{~d}, 1 \mathrm{H}, J_{\mathrm{a}-\mathrm{b}}=10.9 \mathrm{~Hz}, \mathrm{CH}_{2} \mathrm{Ph}\right) ; 4.61\left(\mathrm{~d}, 1 \mathrm{H}, J_{\mathrm{a}^{\prime}-}\right.$ 
$\left.\mathrm{b}=12.3 \mathrm{~Hz}, \mathrm{CH} \mathrm{H}_{2} \mathrm{Ph}\right) ; 4.67\left(\mathrm{~d}, 1 \mathrm{H}, \mathrm{CH}_{2} \mathrm{Ph}\right) ; 4.86\left(\mathrm{~d}, 1 \mathrm{H}, \mathrm{CH}_{2} \mathrm{Ph}\right) ; 7.18-7.29(\mathrm{~m}, 15 \mathrm{H}, 15 \mathrm{H}-$ aro). ${ }^{13} \mathrm{C} \mathrm{NMR}\left(\mathrm{CDCl}_{3}\right)$, $\delta: 31.77(\mathrm{C}-6) ; 40.83\left(\mathrm{OCH}_{3}\right) ; 52.90,52.93\left(2 \mathrm{OCH}_{3}\right) ; 55.19(\mathrm{C}-7)$; 69.48 (C-5); $72.62\left(\mathrm{CH}_{2} \mathrm{Ph}\right) ; 73.28\left(\mathrm{CH}_{2} \mathrm{Ph}\right) ; 75.06(\mathrm{C}-2) ; 75.60\left(\mathrm{CH}_{2} \mathrm{Ph}\right) ; 79.10(\mathrm{C}-4) ; 80.51$

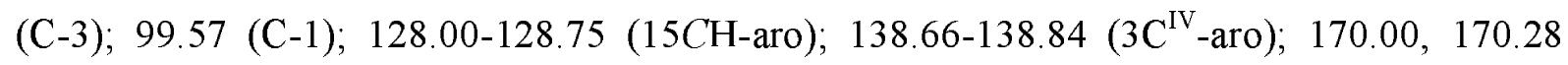
(2CO). $\mathrm{MS} \mathrm{ESI}^{+}, m / z: 601.28[\mathrm{M}+\mathrm{Na}]^{+}$.

\section{9. (Methyl 2,3,4-tri- $O$-benzyl-6,7-dideoxy-7-carboxy- $\alpha$-D-manno-octopyranosid)uronic acid 8}

To a cooled $\left(0{ }^{\circ} \mathrm{C}\right)$ solution of $4 \mathrm{~N} \mathrm{NaOH}(1,3 \mathrm{~mL})$ was added dropwise a solution of 7 (584 $\mathrm{mg}, 1.01 \mathrm{mmol})$ in $\mathrm{THF} /$ water $(4 / 6 \mathrm{v} / \mathrm{v}, 5 \mathrm{~mL})$. The mixture was sonicated at room temperature in an ultrasonic bath. After $35 \mathrm{~min}$, the reaction was complete, as revealed by TLC. The mixture was acidified with a solution of $5 \mathrm{~N} \mathrm{HCl}$ until $\mathrm{pH} 4.0$ and then, extracted several times with ethyl acetate. The organic layer was washed with brine, dried $\left(\mathrm{Na}_{2} \mathrm{SO}_{4}\right)$ and concentrated. The residue was purified by silica gel column chromatography (light petroleum/AcOEt 95/5 v/v) affording malonic acid $8(528 \mathrm{mg}, 95 \%)$ as a white powder. $R_{f}$ $0.52(\mathrm{AcOEt} / \mathrm{MeOH} 9 / 1) .[\alpha]_{\mathrm{D}}{ }^{20}+30.5\left(c 1.13 / \mathrm{CHCl}_{3}\right) .{ }^{1} \mathrm{H} \mathrm{NMR}\left(\mathrm{CDCl}_{3}\right), \delta: 2.01(\mathrm{~m}, 1 \mathrm{H}$, H-6'); $2.49\left(\mathrm{t}, 1 \mathrm{H}, J_{6-6^{\prime}}=14.0 \mathrm{~Hz}, J_{6-7}=10.7 \mathrm{~Hz}, \mathrm{H}-6\right) ; 3.16\left(\mathrm{~s}, 3 \mathrm{H}, \mathrm{OCH}_{3}\right) ; 3.54\left(\mathrm{t}, 1 \mathrm{H}, J_{5-4}=\right.$ $\left.J_{5-6^{\prime}}=9.5 \mathrm{~Hz}, \mathrm{H}-5\right) ; 3.65-3.70(\mathrm{~m}, 1 \mathrm{H}, \mathrm{H}-7) ; 3.62\left(\mathrm{t}, 1 \mathrm{H}, J_{4-3}=9.5 \mathrm{~Hz}, \mathrm{H}-4\right) ; 3.66\left(\mathrm{dd}, 1 \mathrm{H}, J_{2-1}\right.$ $\left.=1.5 \mathrm{~Hz}, J_{2-3}=2.1 \mathrm{~Hz}, \mathrm{H}-2\right) ; 3.77(\mathrm{dd}, 1 \mathrm{H}, \mathrm{H}-3) ; 4.49\left(\mathrm{~s}, 2 \mathrm{H}, \mathrm{CH}_{2} \mathrm{Ph}\right) ; 4.55(\mathrm{~d}, 1 \mathrm{H}, \mathrm{H}-1)$; $4.58\left(\mathrm{~d}, 1 \mathrm{H}, J_{\mathrm{a}-\mathrm{b}}=10.9 \mathrm{~Hz}, \mathrm{CH}_{2} \mathrm{Ph}\right) ; 4.61\left(\mathrm{~d}, 1 \mathrm{H}, J_{\mathrm{a}^{\prime}-\mathrm{b}}=12.3 \mathrm{~Hz}, \mathrm{CH}_{2} \mathrm{Ph}\right) ; 4.67(\mathrm{~d}, 1 \mathrm{H}$, $\left.\mathrm{CH}_{2} \mathrm{Ph}\right) ; 4.86\left(\mathrm{~d}, 1 \mathrm{H}, \mathrm{CH}_{2} \mathrm{Ph}\right) ; 7.09-7.27$ (m, 15H, 15H-aro); 10.69 (br s, 2OH). ${ }^{13} \mathrm{C}$ NMR $\left(\mathrm{CDCl}_{3}\right), \delta: 31.42(\mathrm{C}-6) ; 48.78\left(\mathrm{OCH}_{3}\right) ; 55.54(\mathrm{C}-7) ; 69.38(\mathrm{C}-5) ; 72.71-73.32\left(2 \mathrm{CH}_{2} \mathrm{Ph}\right)$; 75.07 (C-2); $75.84\left(\mathrm{CH}_{2} \mathrm{Ph}\right) ; 79.10$ (C-4); 80.36 (C-3); 99.52 (C-1); 128.14-129.06 (15CH-

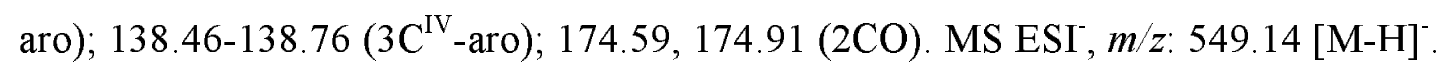

\subsection{Sodium (Methyl 6,7-dideoxy-7-carboxy- $\alpha$-D-manno-octopyranosid)uronate 9}

A suspension of 8 (512 mg, $0.93 \mathrm{mmol})$ and $\mathrm{Pd} / \mathrm{C}(10 \%, 200 \mathrm{mg})$ in EtOH/AcOEt (7/3 v:v) $(20 \mathrm{~mL})$ was vigourously stirred under an $\mathrm{H}_{2}$ atmosphere for $4 \mathrm{~h}$. The reaction was filtered through a Celite pad, and concentrated under reduced pressure. To the residue dissolved in water $(50 \mathrm{~mL})$ was added the cation exchange resin in the $\mathrm{Na}^{+}$form. After $2 \mathrm{~h}$, the resin was filtered off and washed several times wih water. The aqueous phase was lyophilized affording 
$9(292 \mathrm{mg}, 97 \%)$ as a white powder. $R_{f} 0.28\left(\mathrm{NH}_{4} \mathrm{OH} / \mathrm{H}_{2} \mathrm{O} / \mathrm{PPrOH} 1 / 1 / 8\right)$. $[\alpha]_{\mathrm{D}}{ }^{20}+45.78(c$ $\left.1.35 / \mathrm{H}_{2} \mathrm{O}\right) .{ }^{1} \mathrm{H}$ NMR $\left(\mathrm{D}_{2} \mathrm{O}\right), \delta: 1.90-1.96(\mathrm{~m}, 1 \mathrm{H}, \mathrm{H}-6$ '); 2.38-2.42 (m, 1H, H-6); 3.26 (s, 3H, $\left.\mathrm{OCH}_{3}\right) ; 3.40\left(\mathrm{t}, 1 \mathrm{H}, J_{4-3}=J_{4-5}=9.1 \mathrm{~Hz}, \mathrm{H}-4\right) ; 3.44-3.48(\mathrm{~m}, 2 \mathrm{H}, \mathrm{H}-5, \mathrm{H}-7) ; 3.61\left(\mathrm{dd}, 1 \mathrm{H}, J_{3-2}\right.$ $=3.4 \mathrm{~Hz}, \mathrm{H}-3) ; 3.82\left(\mathrm{dd}, 1 \mathrm{H}, J_{2-1}=1.5 \mathrm{~Hz}, \mathrm{H}-2\right) ; 4.61(\mathrm{~d}, 1 \mathrm{H}, \mathrm{H}-1) .{ }^{13} \mathrm{C} \mathrm{NMR}\left(\mathrm{D}_{2} \mathrm{O}\right), \delta: 30.94$ (C-6) ; $52.94\left(\mathrm{OCH}_{3}\right) ; 54.97$ (C-7); 69.87, 70.22, 70.37, 70.69 (C-2,3,4,5); 100.84 (C-1); $174.71,175.07$ (2CO). MS ESI', $m / z: 279.19[\mathrm{M}-2 \mathrm{Na}+\mathrm{H}]^{-}$.

\subsection{Purification of the M6P/IGF2R}

M6P/IGF2R was purified on a phosphomannan-sepharose affinity column, according to the method described by Brouillet ${ }^{19}$ et al. . Fetal calf serum (FCS) $(200 \mathrm{~mL})$ diluted in buffer A $(200 \mathrm{~mL})$ was passed over the PMP-affinity column. The column was washed with buffer A $(40 \mathrm{~mL})$ to remove unbound protein. Then the M6P/IGF2R was specifically eluted with $5 \mathrm{mM}$ mannose 6-phosphate. The different fractions were analysed by SDS-polyacrylamide gel electrophoresis (PAGE) (12\% acrylamide) and protein $(270 \mathrm{kDa})$ was detected by Coomassie blue staining. $672 \mu \mathrm{g}$ of M6P/IGF2R were recovered from $200 \mathrm{~mL}$ of FCS serum.

\subsection{Biotinylation of the M6P/IGF2R}

N-Hydroxysuccinimid biotin in dimethyl sulfoxide $\left(10 \mathrm{mg} \cdot \mathrm{mL}^{-1}\right)$ and the M6P/IGF2R $\left(1 \mathrm{mg} \cdot \mathrm{mL}^{-1}\right)$ in PBS were mixed in a ratio which resulted in $110 \mu \mathrm{g}$ of ester per mg of receptor. The mixture was incubated end over end for $7 \mathrm{~h}$ at room temperature. To stop the reaction, ammonium chloride $2 \mathrm{M}$ was added and stirring was kept for $10 \mathrm{~min}$. Then the receptor was dialysed against PBS to remove excess of biotin. The PBS was changed to Buffer B before use in the binding assay. ${ }^{20}$

\subsection{Binding assay for mannose 6-phosphate analogues.}

Phosphomannan core fragment (i. e. PMP functionalized with $\beta$-( $p$-aminophenyl)ethylamine) (200 $\mu \mathrm{L}$ well, $200 \mu \mathrm{g} \cdot \mathrm{mL}^{-1}$ in Carbonate Buffer) was adsorbed to microtiter wells of an ELISA plate (96 wells) overnight at $4{ }^{\circ} \mathrm{C}$. Then the wells were saturated for $1 \mathrm{~h}$ at room temperature with $1 \%$ gelatine (Type A from Porcine Skin) in PBS $(400 \mu \mathrm{L})$ and washed 5 times with washing buffer $(400 \mu \mathrm{L})$. The analogues $\left(10^{-3} \mathrm{M}\right.$ to $10^{-7} \mathrm{M}$ concentration) and M6P/IGF2R $b\left(2.5 \mu \mathrm{g} \cdot \mathrm{mL}^{-1}\right)$, diluted in Buffer B $+2 \mathrm{mg} \cdot \mathrm{mL}^{-1}$ gelatine, were incubated 20 min. Then these mixtures $(200 \mu \mathrm{L})$ were placed in each well for $2 \mathrm{~h}$ at room temperature. 
After 3 washes, the wells were incubated for $1 \mathrm{~h}$ at room temperature with $310^{-8} \mathrm{M}$ streptavidin peroxidase. After washing, OPD solution was added $\left(0.4 \mathrm{mg} \cdot \mathrm{mL}^{-1}\right)$ and the absorbance was measured after $15 \mathrm{~min}$ at $450 \mathrm{~nm}$.

\subsection{Serum stability and cellular cytotoxicity assays}

The analogue stability was measured at $37{ }^{\circ} \mathrm{C}$ after incubation for various time periods in human serum $(75 \%, v / v)$. The binding affinity of the analogues for M6P/IGF2R was then tested using the assay already described.

The cytotoxicity of the analogues was estimated in human breast-cancer cell lines MDA-MB231 and MCF7. MDA-MB-231 and MCF7 were maintained in Dulbelcco's modified Eagle's medium (DMEM) and in F12/DMEM respectively, with $10 \%$ fetal calf serum and $5 \mu \mathrm{g} \cdot \mathrm{mL}^{-1}$ gentamycin in an atmosphere of $5 \% \mathrm{CO}_{2}$. For each experiment, 5000 cells were plated into 24-well plate for $24 \mathrm{~h}$ and then grown for 4 days with cultured media containing various concentrations in M6P or its analogs $\left(10^{-4} \mathrm{M}\right.$ to $\left.10^{-6} \mathrm{M}\right)$. The cell number was evaluated by MTT (3-(4,5-dimethylthiazol-2-yl)-2,5-diphenyltetrazolium bromide, Sigma) assay. Briefly, $500 \mu \mathrm{L}$ of a MTT solution ( $1 \mathrm{mg} \cdot \mathrm{mL}^{-1}$ in PBS) was added per well and the mixture was allowed to stand for $4 \mathrm{~h}$ at $37^{\circ} \mathrm{C}$. Then the MTT solution was removed and the formazan crystals were dissolved in DMSO/EtOH. The concentration of formazan was then evaluated using a multiplate reader spectrophotometer (Biorad 680) at $540 \mathrm{~nm}$. Each data point resulted from triplicates. 


\section{References and notes}

1. Stein, M.; Zijderhand-Bleekemolen, J.E.; Geuze, H.; Hasilik, A.; von Figura, K. EMBOJ 1987, 6, 2677-2681.

2. Oka, Y.; Rozek, L.M.; Czech, M.P. J. Biol. Chem. 1985, 260, 9435-9442.

3. Kang, J.X.; Li, Y. Proc. Natl. Acad. Sci. USA 1997, 94, 13671-13676.

4. Wowk, M.E.; Trapani, J.A. Microbes and Infection 2004, 6, 752-758.

5. Dennis, P.A.; Rifkin, D.B. Proc. Natl. Acad. Sci. USA 1991, 88, 580-584.

6. O’Gorman, D.B.; Weiss, J.; Hettiaratchi, A.; Firth, S.M.; Scott, C.D. Endocrinology 2002, $143,4287-4294$.

7. Osipo, C.; Dorman, S.; Frankfater, A. Exp. Cell Res. 2001, 264, 388-396.

8. Tong, P.Y.; Gregory, W.; Kornfeld, S. J. Biol. Chem. 1989, 264, 7962-7969.

9. Hoflack, B.; Fujimoto, K.; Kornfeld, S. J. Biol. Chem. 1987, 262, 123-129.

10. Sleat, D.E.; Lobel, P. J. Biol. Chem. 1997, 272, 731-738.

11. Gabel, C.A.; Costello, C.E.; Reinhold, V.N.; Kurz, L.; Kornfeld, S. J. Biol. Chem. 1984, 259, 13762-13769.

12. Freeze, H.H. Arch. Biochem. Biophys. 1985, 243, 690-693.

13. Tong, P.Y.; Kornfeld, S. J. Biol. Chem. 1989, 264, 7970-7975.

14. Vidal, S.; Garcia, M.; Montero, J.-L.; Morère, A. Bioorg. Med. Chem. 2002, 10, 40514056.

15. Mahrwald, R.; Theil, F.; Schick, H.; Schwarz, S.; Palme, H.-J.; Weber, G. J. Prakt. Chem. 1986, 328, 777-783

16. Vidil., C; Vidal, S.; Morère, A.; Montero, J.-L. Phosphorus, Sulfur and Silicon 2000, 158, 125-139.

17. Borén, H. B.; Eklind, K.; Garegg, P. J.; Lindberg, B.; Pilotti, A. Acta Chem. Scand. 1972, 26, 4143-4146.

18. Vidal, S.; Montero, J.-L.; Leydet, A.; Morère, A. Phosphorus, Sulfur and Silicon 2002, 177, 2363-2377.

19. Brouillet, J.-P.; Dufour, F.; Lemamy, G.; Garcia, M.; Schlup, N.; Grenier, J. ; Mani, J.-C.; Rochefort, H. Cancer 1997, 79, 2132-2136.

20. Christensen, M.K.; Meldal, M.; Bock, K.; Cordes, H.; Mouritsen, S.; Elsner, H. J. Chem. Soc., Perkin Trans 1 1994, 1299-1310.

21. Berkowitz, D. B.; Maiti, G.; Charette, B. D.; Dreis, C. D.; MacDonald, R. G. Org. Lett. 2004, 6, 4921-4924.

22. Ferguson, M. W. J.; McNeight, D. L. PCT Int. Appl. WO 97 05, 883, 1997.

23. Perrin, D. D.; Amarego, W. L. F. Purification of Laboratory Chemicals, $3^{\text {rd }}$ ed.; Pergamon Press: New York, 1988.

24. Slodki, M. E.; Ward, R. M.; Boundy, J. A. Biochim. Biophys. Acta 1973, 304, 449-456. 